June 2002 • NREL/SR-500-30876

\title{
Searcher Bias and Scavenging Rates in Bird/Wind Energy Studies
}

M. Morrison

White Mountain Research Station

Bishop, California

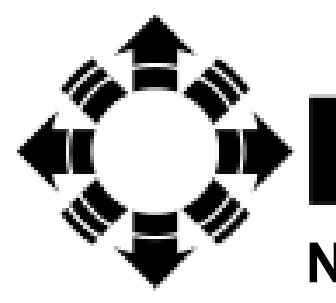

National Renewable Energy Laboratory

1617 Cole Boulevard

Golden, Colorado 80401-3393

NREL is a U.S. Department of Energy Laboratory

Operated by Midwest Research Institute $\bullet$ Battelle $\bullet$ Bechtel

Contract No. DE-AC36-99-G010337 
June 2002 • NREL/SR-500-30876

\title{
Searcher Bias and Scavenging Rates in Bird/Wind Energy Studies
}

\author{
M. Morrison \\ White Mountain Research Station \\ Bishop, California
}

NREL Technical Monitor: K. Sinclair

Prepared under Subcontract No. TAT-1-31200-01

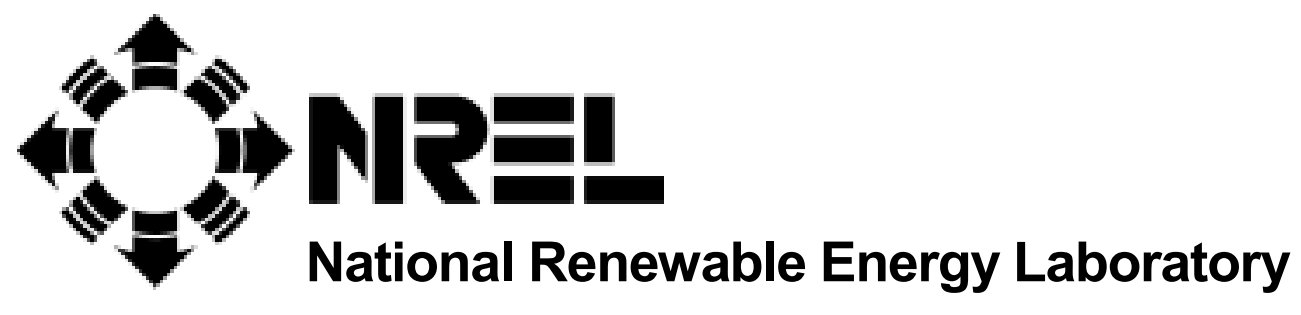

1617 Cole Boulevard

Golden, Colorado 80401-3393

NREL is a U.S. Department of Energy Laboratory

Operated by Midwest Research Institute • Battelle • Bechtel

Contract No. DE-AC36-99-G010337 


\section{NOTICE}

This report was prepared as an account of work sponsored by an agency of the United States government. Neither the United States government nor any agency thereof, nor any of their employees, makes any warranty, express or implied, or assumes any legal liability or responsibility for the accuracy, completeness, or usefulness of any information, apparatus, product, or process disclosed, or represents that its use would not infringe privately owned rights. Reference herein to any specific commercial product, process, or service by trade name, trademark, manufacturer, or otherwise does not necessarily constitute or imply its endorsement, recommendation, or favoring by the United States government or any agency thereof. The views and opinions of authors expressed herein do not necessarily state or reflect those of the United States government or any agency thereof.

Available electronically at http://www.osti.gov/bridge

Available for a processing fee to U.S. Department of Energy

and its contractors, in paper, from:

U.S. Department of Energy

Office of Scientific and Technical Information

P.O. Box 62

Oak Ridge, TN 37831-0062

phone: 865.576.8401

fax: 865.576.5728

email: reports@adonis.osti.gov

Available for sale to the public, in paper, from:

U.S. Department of Commerce

National Technical Information Service

5285 Port Royal Road

Springfield, VA 22161

phone: 800.553.6847

fax: 703.605.6900

email: orders@ntis.fedworld.gov

online ordering: http://www.ntis.gov/ordering.htm

Printed on paper containing at least $50 \%$ wastepaper, including $20 \%$ postconsumer waste 


\section{Introduction}

The commercial production of electricity using wind power has been increasing in the United States and Europe since the 1970s. The potential environmental impact of wind energy development in regard to birds dying because of collisions with wind turbine blades has been an issue of concern. This concern was highlighted because of high rates of collisions at the Altamont Pass Wind Resource Area (WRA) in California, where an estimated 30-40 golden eagles and hundreds of other raptors are being killed annually (Orloff and Flannery 1992). Although high rates of fatalities have been found in some studies in Europe (AWEA 1995), no other study in North America has documented as high a rate of kill as that at Altamont Pass WRA. Nevertheless, concern by various individuals, organizations, and government agencies led to the creation of standardized and rigorous methods of evaluating bird fatalities in existing and planned wind developments (Anderson, Morrison, Sinclair, and Strickland 1999).

Evaluation of the impact of wind developments on birds (and bats) requires quantification of fatality rates because of collisions with rotating turbine blades. Such quantification requires sampling for dead animals around turbines. However, it is well known that observers vary in their ability to detect objects in the field (Morrison, Block, Strickland, and Kendall 2001). Such variation is due, in part, to innate differences in observers (e.g., physical ability or eyesight), training, and interest in the study. Searching for animals killed by turbines is inherently difficult because it often requires locating small objects in poor condition in dense vegetation (e.g., grass or shrubs) on steep terrain. Additionally, the ability of even trained observers to locate objects may change because of fatigue and extreme weather. Thus, estimates of animal fatalities in wind developments are biased to unknown degrees by inefficiencies of observers.

Estimates of fatalities are also biased by the removal of carcasses by scavenging animals or other actions (e.g., wind, plowing) before their detection by observers. All wind developments will be inhabited by various species of scavengers, primarily birds (e.g., vultures, ravens and other corvids) and mammals (e.g., squirrels, skunks, and coyotes). Thus, infrequent or unplanned surveys for carcasses can result in extremely biased and likely underestimated quantification of the impacts on animals in the development. Scavenging activity will vary seasonally because of the movement and activity patterns of the scavengers and the size of the carcass, further complicating evaluation of the influence of scavenging on collision data.

The influence of searcher efficiency and scavenging on bird/wind energy studies has been recognized (Anderson, Morrison, Sinclair, and Strickland 1999). The goal of this report is to summarize results of searcher efficiency and scavenging, thus providing a guide for workers designing or interpreting bird/wind energy studies.

\section{Methods}

Published papers and unpublished reports and correspondence available through the Avian Literature Database of the National Renewable Energy Laboratory 
(http://www.nrel.gov/wind/avianlit.html) was searched for studies reporting bird or bat fatalities in wind developments. The material obtained from this initial search was examined to determine whether studies of searcher efficiency or scavenging were included. This survey was not meant to be comprehensive; rather, it was designed to obtain an estimate of the influence of searcher efficiency and scavenging on reports of animal fatalities. There are numerous unpublished reports that have been produced by private wind operators that were not available for examination.

\section{Results}

\section{Searcher efficiency}

Strickland et al. (2000) and Strickland, Johnson, and Erickson (no date) reported that searcher efficiency rates averaged between $35.3 \%$ and $38.7 \%$ at Buffalo Ridge, Minnesota. At their Vansycle Ridge, Oregon, study site, Strickland, Johnson, and Erickson (no date) found searcher efficiency of 50\% for small birds and $87.5 \%$ for large birds. Efficiency varied by vegetation type, with $56.7 \%$ of birds (all sizes) recovered in grasslands and 76\% recovered in wheat stubble. Higgins, Dieter, and Usgaard (1995) also found a vegetation effect, with $81.8 \%$ recovery of doves and partridges in cropland, and 63.3\% recovery in Conservation Reserve Program grassland. At Green Mountain, Vermont, searcher efficiency averaged 55\% (Kerlinger 2000). At San Gorgonio, California, Kirtland (1985) calculated observer recovery rates of chicks in grassland from $67 \%-100 \%$ (six plots), with overall recovery of $86 \%$. In Shirley, Wisconsin, Howe and Atwater (1999) reported searcher efficiency at 40\%-50\%.

\section{Scavenging rates}

Strickland et al. (2000) and Strickland, Johnson, and Erickson (no date) reported the mean length of stay for carcasses was between six and seven days for birds and about 10 days for bats at Buffalo Ridge, Minnesota. Also at Buffalo Ridge, Higgins, Dieter, and Usgaard (1995) reported scavenging at 12 of 15 carcasses $(80 \%)$ present after one week (two trials). At Vansycle Ridge, Oregon, Strickland, Johnson, and Erickson (no date) showed that large bird carcasses remained for 26.7 days, while small birds remained for 23.4 days. Results varied by season, with all-size bird carcasses remaining for relatively shorter periods in spring (18.1 days), moderate lengths in fall (23.3 days) and winter (26.5 days), and relatively longer periods in summer (39.8 days). At Green Mountain, Vermont, Kerlinger (2000) also showed a seasonal effect for carcass removal. In June trials, he found $15 \%$ loss in two days and $80 \%$ loss in two months. In September trials, he found a similar loss (20\%) in one week, a 35\% loss in two weeks, and no loss thereafter. At Tehachapi Pass, Orloff and Flannery (1992) found no scavenging of 14 raptor carcasses in a single seven-day trial. Also at Tehachapi Pass, Mitchell et al. (1991) [in Orloff (1992)] found scavenging rates of $29 \%$ in five days and $39 \%$ loss in seven days.

For San Gorgonio, using chicks, Kirtland (1985) found a 57\% loss after five days. Howe and Atwater (1999) found a 25\% loss due to scavenging within 10 days at Shirley, Wisconsin. At Altamont Pass, Howell and DiDonate (1991) found that scavenging resulted in about $50 \%$ loss of fresh game hen carcasses in three days. At Altamont Pass 
and Montezuma Hills (Solano County, California), Howell and Noone (1992, Figure 15) conducted trials of 12 to 14 days duration using raptor and game hen carcasses. Removal rates ranged between about 5\% and $45 \%$ for all except one trial, in which nearly $100 \%$ of the game hens were removed. Smaller raptors were removed at much higher rates than larger raptors.

\section{Discussion}

Results of this survey indicate that searcher efficiency is highly variable, with several studies reporting relatively low rates (i.e., 35\%-50\%) and several studies reporting relatively high rates (i.e., $75 \%-85 \%$ ) of recovery. Few studies considered the influence of vegetation type on searcher efficiency. Studies testing vegetation type indicated that efficiency can, in fact, be influenced by the height and type of vegetation present. Additionally, the size of the bird used in the trials substantially influenced results. For example, Strickland, Johnson, and Erickson (no date) showed that only about $50 \%$ of small birds, compared to about $87 \%$ of larger birds (raptors), were recovered.

The causes for variations in searcher efficiency during and between studies appears to be a function of (1) observer training, (2) vegetation type (and seasonal effects on plant development), and (3) size of bird. It is evident that relatively small birds are being missed at high rates, with most studies likely underestimating the fatality of small birds by $50 \%-75 \%$. Results also indicate that corrections for observer efficiency need to be based on vegetation type, plant phenology (season), and bird (or bat) size.

Studies of scavenging rates were also highly variable and were influenced by bird size and season. Results did show a trend toward a substantial $(50 \%-75 \%)$ loss of carcasses of small to midsize birds within one to four weeks. Few studies followed carcasses for more than a few weeks, which renders estimates of the eventual fate of larger carcasses difficult. It appears, however, that in certain locations even large raptors will disappear after a month or so.

\section{Conclusions and Recommendations}

This survey indicates that estimates of animal fatalities in wind developments should incorporate correction factors based on observer efficiency and scavenging rates. Because observer efficiency and scavenging are influenced by season and vegetation, these correction factors should be calculated based on season- and vegetation-specific data for every study and should not rely on literature values because of substantial variability between studies. Scavenging trials should be conducted for a period of time sufficient to detect when an asymptote in loss occurs (if indeed an asymptote occurs). These data will thus help determine the optimal period of time between carcasses searches. Estimates of total bird or bat fatalities should be determined after correcting for searcher bias and carcass removal bias; Strickland et al. (2000) present methods and calculations. Additionally, before beginning any study, field methods typically used to locate carcasses and conduct experimental trials of observer and carcass removal biases should be reviewed (e.g., Strickland et al. 2000). 


\section{References}

American Wind Energy Association. (1995). Avian Interactions with Wind Energy Facilities: A Summary. Washington, D.C.: American Wind Energy Association.

Anderson, R.; Morrison, M; Sinclair, K.; Strickland, D. (1999). Studying Wind Energy/Bird Interactions: A Guidance Document. Washington, D.C.: National Wind Coordinating Committee.

Higgins, K.F.; Dieter, C.D.; Usgaard, R.E. (1995). Monitoring of Seasonal Bird Activity and Mortality on Unit 2 at the Buffalo Ridge Windplant, Minnesota. San Francisco, CA: Kenetech, Inc.

Howe, R.W.; Atwater, R. (1999). The Potential Effects of Wind Power Facilities on Resident and Migratory Birds in Eastern Wisconsin. Unpublished report, Wisconsin Department of Natural Resources, 29 March 1999.

Howell, J.A; DiDonate, J.E. (1991). Assessment of Avian Use and Mortality Related to Wind Turbine Operations, Altamont Pass, Alameda and Contra Counties, California. Final report. Livermore, CA: U.S. Windpower.

Howell, J.A.; and Noone, J. (1992). Examination of Avian Use and Mortality at a U.S. Windpower Wind Energy Development Site, Montezuma Hills, Solano County, California. Fairfield, CA: Department of Environmental Management, Solano County.

Kerlinger, P. (2000). "An Assessment of the Impacts of Green Mountain Power Corporation's Searsburg, Vermont, Wind Power Facility on Breeding and Migratory Birds." Proceedings of National Avian-Wind Power Planning Meeting III, San Diego, California, May 1998. Washington, D.C: National Wind Coordinating Committee, pp. 90-96.

Kirtland, K. (1985). Wind Implementation Monitoring Program: A Study of Collisions of Migrating Birds with Wind Machines. Riverside, CA: Riverside County Planning Department.

Morrison, M.L.; Block, W.M.; Strickland, M.D.; Kendall, W.L. (2001). Wildlife Study Design. New York: Springer-Verlag.

Orloff, S. (1992). Tehachapi Wind Resource Area Avian Collision Baseline Study. Sacramento, CA: California Energy Commission.

Orloff, S.; Flannery, A. (1992). Wind Turbine Effects on Avian Activity, Habitat Use, and Mortality in Altamont Pass and Solano County Wind Resource Areas. Work performed by BioSystems Analysis, Inc., Tiburon, CA. Sacramento, CA: California Energy Commission. 
Strickland, M.D.; Johnson, G.D.; Erickson, W.P.; Sarappo, S.A.; Halet, R.M. (2000).

"Avian Use, Flight Behavior, and Mortality on the Buffalo Ridge, Minnesota Wind

Resource Area." Proceedings of National Avian-Wind Power Planning Meeting III, San

Diego, California, May 1998. Washington, D.C.: National Wind Coordinating

Committee, pp. 70-79.

Strickland, M.D.; Johnson, G.; Erickson, W.P. (No date). Avian Studies at Wind Plants

Located at Buffalo Ridge, Minnesota, and Vansycle Ridge, Oregon. Unpublished report.

Cheyenne, WY: WEST, Inc. 


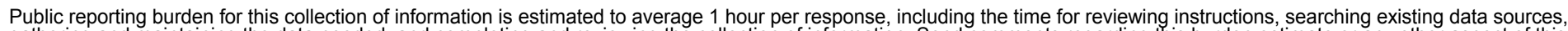

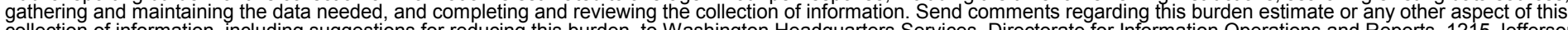

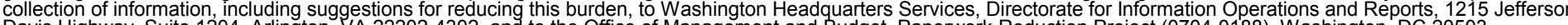
Davis Highway, Suite 1204, Arlington, VA 22202-4302, and to the Office of Management and Budget, Paperwork Reduction Project (0704-0188), Washington, DC 20503.
1. AGENCY USE ONLY (Leave blank)
2. REPORT DATE June 2002
3. REPORT TYPE AND DATES COVERED Subcontractor report

4. TITLE AND SUBTITLE

Searcher Bias and Scavenging Rates in Bird/Wind Energy Studies

6. $\operatorname{AUTHOR}(\mathrm{S})$

M. Morrison

7. PERFORMING ORGANIZATION NAME(S) AND ADDRESS(ES)

White Mountain Research Station

8. PERFORMING ORGANIZATION

3000 East Line Street

Bishop, California 93514

9. SPONSORING/MONITORING AGENCY NAME(S) AND ADDRESS(ES)

National Renewable Energy Laboratory

1617 Cole Blvd.

Golden, CO 80401-3393

5. FUNDING NUMBERS

C: TAT-1-31200-01

TA: WER2.1610 REPORT NUMBER

11. SUPPLEMENTARY NOTES

NREL Technical Monitor: Karin Sinclair

12a. DISTRIBUTION/AVAILABILITY STATEMENT

National Technical Information Service

U.S. Department of Commerce

5285 Port Royal Road

Springfield, VA 22161

13. ABSTRACT (Maximum 200 words)

Estimates of animal fatalities in wind developments are biased to unknown degrees by inefficiencies of observers and by the removal of carcasses by scavenging animals or other actions before their detection by observers. This report summarizes results of searcher efficiency and scavenging, thus providing a guide for workers designing or interpreting bird/wind energy studies. Searcher efficiency is highly variable, with several studies reporting relatively low rates (i.e., $35 \%-50 \%$ ) and several studies reporting relatively high rates (i.e., $75 \%-85 \%$ ) of recovery. The few studies that tested vegetation type indicated that efficiency is influenced by the height and type of vegetation present. It is evident that relatively small birds are being missed at high rates, with most studies likely underestimating the fatality of small birds by $50 \%-75 \%$. Results also indicate that corrections for observer efficiency need to be based on vegetation type, plant phenology (season), and bird (or bat) size. Studies of scavenging rates were also highly variable and were influenced by bird size and season. Results did show a trend toward a substantial $(50 \%-75 \%)$ loss of carcasses of small to midsize birds within one to four weeks; even large raptors will disappear after a month or so.

14. SUBJECT TERMS wind energy, avian research, searcher bias

15. NUMBER OF PAGES

16. PRICE CODE

17. SECURITY CLASSIFICATION OF REPORT

Unclassified
18. SECURITY CLASSIFICATION OF THIS PAGE Unclassified
19. SECURITY CLASSIFICATION OF ABSTRACT Unclassified
20. LIMITATION OF ABSTRACT

UL 